\title{
Genre et développement : bibliographie sélective
}

Danielle de Lame

\section{(2) OpenEdition}

Journals

Édition électronique

URL : http://journals.openedition.org/apad/257

DOI : 10.4000/apad.257

ISSN : 1950-6929

Éditeur

LIT Verlag

Édition imprimée

Date de publication : 20 décembre 2000

\section{Référence électronique}

Danielle de Lame, "Genre et développement : bibliographie sélective », Bulletin de l'APAD [En ligne], 20 | 2000, mis en ligne le 10 avril 2006, consulté le 07 septembre 2020. URL : http://

journals.openedition.org/apad/257 ; DOI : https://doi.org/10.4000/apad.257

Ce document a été généré automatiquement le 7 septembre 2020.

Bulletin de l'APAD 


\title{
Genre et développement : bibliographie sélective ${ }^{1}$
}

\author{
Danielle de Lame
}

1 La bibliographie ci-dessous n'a pas été systématisée. C'est un choix. Mon espoir est que la curiosité de parcourir cette liste peu exhaustive mais très éclectique fera découvrir au passage des voies non encore explorées par le voyageur spécialiste de tel ou tel terrain théorique ou spatial. Cette liste ouvre les pistes que ce bulletin n'a pu investiguer, même s'il recouvre des tendances essentielles des études actuelles à propos du genre : apports théoriques de l'approche (Lachenman), réappropriation locale des programmes (Pireaux et Boutinot), marquage de genre des activités de production (Mwaipopo), idéologie et critique idéologique de la promotion des femmes (Nyanchama-Okemwa).

2 Le parcours entre les références bibliographiques, en majorité postérieures à 1990, fait découvrir une prise de conscience de l'omniprésence du marquage de genre des phénomènes sociaux et culturels. Cependant, si quelques auteurs masculins (e.a. Shoenbrunn, 2000, A Green Place, a Good Place... ) prennent argument commercial du "genre" figurant parfois un peu abusivement dans le titre de leur ouvrage, la plupart du temps, ce sont des femmes qui adoptent une optique "genre" dans l'analyse des faits sociaux et elles le font, le plus souvent encore, à partir d'un point de vue de femme ou du point de vue des femmes. Fossé de connaissance à combler ? Droit d'une "minorité" majoritaire à restaurer? Combats à illustrer? Une part de militantisme subsiste sans doute. Peut-être aussi, dans la foulée des courants post-modernes, la pluralité des destins trouve-t-elle à se faire entendre. Enfin, et sans aucun doute, comme le souligne G. Lachenman dans son texte, les dichotomies habituelles se sont montrées inefficaces à rendre compte de la complexité des phénomènes sociaux dans des contextes mouvants et dans des cadres théoriques qui se veulent aptes à capter les dynamiques sociales. C'est sur ce terrain des dynamiques sociales, me semble-t-il, que le genre devrait le moins se confondre avec le genre féminin. Sur ce plan, beaucoup reste à faire, plus encore que sur le terrain, encore quasi vierge, de l'étude des masculinités. Enfin, la prise en compte des dynamiques sociales de genre amène à considérer les rapports de 
pouvoir auxquelles elles s'entrecroisent dans la poursuite d'un accès aux ressources naturelles, culturelles ou monétaires. La prise en compte de l'ensemble des rapports de pouvoir dans l'analyse des problématiques liées au développement est une optique que l'APAD poursuit depuis ses débuts. Mon souhait est que ce bulletin contribue à aborder, comme allant de soi, l'aspect "genre" des rapports sociaux et des dynamiques que ceux-ci incarnent.

\section{BIBLIOGRAPHIE}

Abdullah H., 1993, "Transition politics and the challenge of gender in Nigeria", Review of African Political economy, $\mathrm{n}^{\circ} 56: 27-37$.

Adams M., 1994, "Négociations entre hommes et femmes dans un village ivoirien", Journal des Africanistes, 64, $2:$ 65-88.

Adepoju A., Oppong C., 1994, Gender, work and population in Sub-Saharan Africa, London, J. Currey.

Adomako A.A., 1997, "Costs and rewards, exchange in relationships. Experiences of some Ghanaian women, in Rosander E.E., Transforming female identities. Women's organizational forms in West Africa, Uppsala, Nordiska Afrikainstitutet : 177-196.

Andrae G., 1997, "A woman worker in a Lagos factory. Her power base in family, community, labour market and union", in Rosander E.E., Transforming female identifies. Women's organizational forms in West Africa, Uppsala, Nordiska Afrikainstitutet : 69-84.

Anyanwu J.C., 1991, "Women, education, and the use of bank credit in Nigeria : challenges for the twenty-first Century", Ufahamu, 19, 2-3 : 130-145.

Baerends E.A., 1998, "Changing kinship. Family and gender relations in Sub-Saharan Africa", in Risseuw C. \& K. Ganesh, Negotiation and social space : 47-86.

Bagla-Gökalp L., 1999, "Des théories féministes d'hier aux débats sociaux d'aujourd'hui", in Jonckers D., Carré R. \& Dupré M.C., Femmes plurielles. Les représentations des femmes : discours, normes et conduites, Paris, Maison des Sciences de l'Homme : 271-288.

Bank L., 1997, "The social life of Paraffin. Gender, domesticity and the politics of value in a South African township", African Studies, 56, $2:$ 157-179.

Basu A., 1995, The Challenge of Local Feminisms. Women's Movements in Global Perspective, Boulder, Westview Press.

Bernal V., 1994, "Gender, culture and capitalism : women and the remaking of Islamic "tradition" in a Sudanese village", Comparative studies in society and history, 36, $1: 36-67$.

Besteman C., 1995,"'Polygyny, women's land tenure, and the "mother-son partenership" in Southern Somalia" , Journal of Anthropological Research, 51, 3 : 193-213

Boyd R.E., 1989, "Empowerment of women in Uganda : real or symbolic", Review of African Political Economy, n $45-46$ : 106-117. 
Broude G.J., 1990, "The division of labor by sex and other gender-related variables : an exploratory study", Behavior Science Research, 24, 1-4 : 29-49.

Burton M., 1996, "Constructing a scale of female contributions to agriculture : methods for imputing missing data", Cross Cultural Research, 30, 1:3-23.

Byrne B., 1994, "Access to subsistence resources and the sexual division of labor among potters", Cross Cultural Research, 28,3:225-250.

Chieni T., Spencer P., 1993, "The world of Telelia. Reflections of a Maasai woman", in Spier Th. \& Waller R., Being Maasai, London, J. Currey : 157-173.

Cock J., 1989, "Keeping the fires burning : militarisation and the politics of gender in South Africa". Review of African Political Economy, $n^{\circ} 45-46$ : 50-64.

Comaroff J.L., 1987, "Sui genderis : feminism, kinship theory, and structural 'domains'", in Collier J.F. \& Yanagisako S.J., Gender and kinship. Essays toward a unified analysis, Stanford, Stanford University Press : 53-85.

Cordell D.D., Gregory J., Piché V., 1998, Hoe and wage. A social history of a circular migration system in West Africa, Oxford, Boulder, Westview Press.

Crehan K., 1997, The fractured community. Landscapes of power and gender in rural Zambia, Berkeley. Los Angeles, London, University of California Press.

Crumbley D.H., 1985, "Even a woman : sex roles and mobility in a Aladura society", West African Journal of Archaeology, 15 : 133-149.

D'Azevedo W.L., 1994, "Gola womanhood and the limits of masculine omnipotence", in Blakely Th.D. \& Van Beek W.E., Religion in African. Experience and expression, London, James Currey : 343-362.

Daniels E., 1996, "The impact of the 1992 constitution on family rights in Ghana", Journal of African Law, 60, 2 : 183-193.

David S., 1996, "You become one in marriage : domestic budgeting among the Kpelle of Liberia", Revue canadienne des études africaines. 30, $2: 157-182$.

Davison J., 1993, "Tenacious women : clinging to Banja household production in the face of changing gender relations in Malawi", Journal of Southern African Studies, 29, 3 : 405-421.

Davison J., 1998, "Changing gender relations of production in Mozambique since independence : an unfinished agenda", Africana Journal $17: 164-184$.

De Boeck F., 1994, "When hunger goes around the land: hunger and food among the Aluund of Zaire", Man, 29, 2 : 257-282.

De Boeck F., 1999, "Dogs breaking their leash : globalization and shifting gender categories in the diamond traffic between Angola and DRCongo" in De Lame D. \& Zabus C., Changements au féminin en Afrique Noire, vol. 1 : Anthropologie, Paris, l'Harmattan : 87-114.

De Lame D., 1999, "Que sont mes amis devenus? Se recréer des rapports de genre", in De Lame D. \& Zabus C., Changements au féminin en Afrique Noire, vol. 1 : Anthropologie, Paris, l'Harmattan : 17-36.

De Lame D., 1999, "Idéologies d'ici et là : des Rwandaises et une anthropologue", in Jonckers D., Carré R. \& Dupré M.C., Femmes plurielles. Les représentations des femmes : discours, normes et conduites, Paris, Maison des Sciences de l'Homme : 37-56.

De Lame D., Zabus C., 1999, Changements au féminin en Afrique Noire, vol.1 :Anthropologie, vol II : Littérature, Paris, l'Harmattan. 
Drews A., 1995, "Covering and uncovering. Secrets and the construction of gender identity among the Kunda of Zambi", Medische anthropologie, 8, $1: 101-113$.

Drucker-Brown S., 1993, "Mamprusi witchcraft, subversion and changing gender relations", Africa, 53,4 : 531-549.

Ebam Etta F., 1999, Makolo low-income settlement in Lagos, Nigeria. Gender and urban natural resources management, in Lee-Smith D., Women managing resources. African research on gender, urbanisation and environment, Nairobi, Mazingira Institute : 41-51.

Etienne M., 1987, "Rapports de sexe et de classe et mobilité socio-économique chez les Baoulé (Côte d'Ivoire)", Anthropologie et Sociétés, 11, 1 : 71-93.

Fall Y., 1997, "Gender relations in the democratization process : an analysis of agrarian policies, in Africa", Issue $25,2: 8-11$.

Francis E., 1995, "Migration and changing divisions of labour : gender relations and economic change in Koguta, Western kenya", Africa, 65,2 : 197-216.

Ganesh K., Risseeuw C., 1998, Introduction : gendered change in marriage and family. A policy concern, in Risseuw C. \& Ganesh K., Negotiation and social space : 11-43.

Gawanas B., 1993, "Legal rights of Namibian women and affirmative action : the eradication of gender inequalities", Review of African Political Economy, $n^{\circ} 56$ : 116-119.

Geisler G., 1987, "Sisters under the skin : women and the Women's League in Zambia", Journal of Modern African Studies, 25, 1 : 43-66.

Glick P., Sahn D., 1997, "Gender and education impacts on employment and earnings in West Africa : evidence from Guinea", Economic Development and Cultural Chang, 45,4 : 793-823.

Goheen M., 1993, "Les champs appartiennent aux hommes, les récoltes aux femmes : accumulation dans la région de Nso", in Geschiere P. \& Konings P., Itinéraires d'accumulation au Cameroun, Paris, Karthala : 241-271.

Goheen M., 1995, "Gender and accumulation in Nso", Paideuma, 41 : 73-81.

Gondola C.D., 1999, "Bisengo ya la joie. Fête, sociabilité et politique dans les capitales congolaises", in Goerg O., Fête urbaines en Afrique, Paris, Karthala : 87-111.

Gondola C.D., 1997, "Oh, rio-Ma! Musique et guerre des sexes à Kinshasa, 1930 -1990", Revue française d'Histoire d'Outre-Mer, 84, 314 : 51-81.

Guseh J.S., 1994, "Sexual harassment in Liberia : a review", Liberian Studies Journal,19,2 : 183-196.

Gutmann M., 1997, "Trafficking in men : the anthropology of masculinity", Annual Review of Anthropology, 26 : 385-409.

Guyot D., 1993, "Contribution à l'analyse des relations entre stratification sociale, raciale et sexuelle : le cas des métis togolais", Cahiers d'Etudes africaines,33, $3:$ 403-417.

Haddad L., Readon T., 1993, "Gender bias in the allocation of resources within households in Burkina Faso : a disaggregated outlay equivalent analysis", Journal of Development Studies, 29, 2 : 260-276.

Hakansson N.T., Levine R.A., 1997, "Gender and life-course strategies among the Gusii", in Hakansson N.T. \& Levine R.A., African families and the crisis of social change, Westport, London, Bergin \& Garvez : 253-267. 
Hale S., 1992, "The rise of Islam and women of the National Islamic Front in Sudan", Review of African Political Economy, ${ }^{\circ} 54$ : 27-41.

Hall R., 1998, "Design for equity : linking policy with objectives in South Africa's land reform", Review of African Political Economy, $\mathrm{n}^{\circ} 77$ : 451-462.

Hamer J., Hamer I., 1994, "Impact of a cash economy on complementary gender relations among the Sadama of Ethiopia", Anthropological quaterly, 67,4:187-202.

Hamid A., Rahman S., Mohamedani A., Mubarak Mirgani E., Mahgoub I., 1996, "Gender aspects and women's participation in the control and management of malaria in Central Sudan", Social Science and Medicine, 42, $10: 1433-1446$.

Hannequin Br., 1990, "Etat, patriarcat et développement : le cas d'un village mossi du Burkina Faso", Revue canadienne des Etudes africaines, 24, $1: 36-49$.

Hardenbergh S., 1997, "Why are boys so small ? Child growth, diet and gender near Ranomafana, Madagascar", Social Science and Medicine, 44, $11: 1725-1738$.

Hazel R., 1980, "Traire la vache et faire l'amour. Une réinterprétation des thèses de Y. Elam sur les Hima d'Ankole (Ouganda)", Anthropologie et Sociétés, 4,3 : 117-135.

Hendrix L., 1994, "What is sexual inequality? On the definition and range of variation", Cross-Cultural Research, 28,3 : 287-307.

Héritier P., 1996, Masculin/Féminin. La pensée de la différence, Paris, Odile Jacob.

Hodgson D., Mac Curdy S., 1996, "Wayward wives, misfit mothers, and disobedient daughters : "wicked" women and the reconfiguration of gender in Africa", Revue canadienne des Etudes africaines, 30, $1: 1-9$.

Hodgson D., 1996, "'My daughter belongs to the Government now' : marriage, Maasai and the Tanzanian State", Revue Canadienne des Etudes africaines, 30, $1:$ 106-123.

Hodgson D.L., 1997, The politics of gender, ethnicity and "development" images, interventions and the reconfiguration of Maasai identities... Ann Arbor, UMI Dissertation Services.

Hollos M., 1991, "Migration, education, and the status of women in Southern Nigeria", American Anthropologist, 93, $4:$ : 852-870.

Holtedahl L., 1993, "Education, economics and "the good life" : women in Ngaoundéré, Northem Cameroon", in Geschere P. \& Konings P., Itinéraires d'accumulation au Cameroun, Paris, Karthala : 273-300.

Hubbard D., Solomon C., 1995, The many faces of feminism in Namibia, in Basu A., The challenge of local feminisms. Women's movements in global... : 163-186.

Ibrahim F.A., 1996, "Sudanese women's union : strategies for emancipation and the counter movement", Ufahamu, 24,2:3-20.

Iyam D., 1996, " 'Full' men and 'powerful' women : the reconstruction of gender statua" among the Biase of Southem Nigeria", Revue canadienne des Etudes africaines.30,3 : 387-408.

Jeffremovas V., 1991, "Loose women, virtuous wives, and timid virgins : gender and the control of resources in Rwanda", Revue canadienne des Etudes africaines. 25, $3: 378-395$.

Johnson Riley P., Krogman N.T., 1993, "Gender-related factors influencing the viability of irrigation projects in Lesotho", Journal of Asian and African Studies, 28, 3-4 : 162-179. 
Jonckers D, Carré D., Dupré M.C., 1999, Femmes plurielles. Les représentations des femmes : discours, nonnes et conduites, Paris, Maison des Sciences de l'Homme.

Kabira W.M., Masinjila M., 1997, Towards gender responsive politics, Nairobi, Friedrich Ebert Foundation.

Kaler A., 1998, "A threat to the nation and a threat to the men : the banning of Depo-provera in Zimbabwe", Journal of Southern African Studies, 24,2 : 347-376.

Kanji N., Jazdowska N., 1993, "Structural adjustment and women in Zimbabwe", Review of African Political Economy, $\mathrm{n}^{\circ} 56$ : 11-26.

Kapteijns L., 1995, "Gender relations and the transformation of the Northern Somali pastoral tradition", International Journal of African Historical Studies, 28,2 : 241-259.

Kent S., 1995, "Does sedentarization promote gender inequality? A case study from the Kalahari", Journal of the Royal Anthropological Institute, 1, 3 : 513-536.

Kiluva-Ndunda M.M., 2001, Women's agency and educational policy. The experience of the women of Kilome, Kenya, Albany, State University of New York Press.

Kipuri N.N.O., 1997, Maasai women in transition : class and gender in the transformation of a pastoral society, Michigan, Ann Arbor, UMI Dissertation Services.

Koczberski G., 1998, "Women in development : a critical analysis", Third World Quarterly, 19, 3 : 395-409.

Kopytoff I., 1990, "Women's roles and existential identities", in Beyond the second sex : new directions in the Anthropology of Gender : 77-97.

Kwagaka B., 1999, Katoogo and Kawaala low-income urban settlements in Kampala, Uganda. Gender and the management of urban environmental health, in Lee-Smith D., Women managing resources. African research on gender, urbanisation and environment, Nairobi, Mazingira Institute : 80-103.

Lachaud J.P., 1997, "Exclusion du marché du travail, inégalité et "genre" dans les capitales africaines : une méthode nouvelle de mesure", Tiers-Monde, 38, n 152 : 777-799.

Lacheman G., 1994, "Civil society and social movements in Africa", in Les associations paysannes en Afrique : 61-95.

Le Palec A., 1997, "Un virus au cœur des rapports sociaux de sexe", Journal des Anthropologues, n 68-69: 111-127.

Lebeau Y., 1997, "The daughters of evil ! Images de l'étudiante sur les campus nigérians", Politique africaine, $\mathrm{n}^{\circ} 65: 21-34$.

Lecarme M., 1999, "La "fatigue" des femmes, le "travail de la mère" en milieu populaire dakarois", in Jonckers D., Carré R. \& Dupré M.C., Femmes plurielles. Les représentations des femmes : discours, nonnes et conduites, Paris, Maison des Sciences de l'Homme : 255-269.

Lee-Smith D., 1999, Women managing resources. African research on gender, urbanisation and environment, Nairobi, Mazingira Institute.

Lewis J., 1998, "Deadlier than the male ? Women, knowledge and power", Africa, 48, 2 : 284-293.

Leys C., 1994, "African capitalists and development : theoretical questions", in Berman B.J., Leys

C., African capitalists in African development, Boulder \& London, Lynne Rienner Publishers : 11-38. 
Liatto-Katundu B., 1993, "The women's lobby and gender relations in Zambia", Review of African Polical Economy, n $56: 79-83$.

Liebenberg A., 1997, "Dealing with relations of inequality. Married women in a Transkei village", African Studies, 56, $2: 349-373$.

Little P., 1994, Maidens and milk markets : the sociology of dairy marketing in Southern Somalia, in Fratkin E. ; Galvin K.A. \& Roth E.A, African pastoralist systems. An integrated approach, London, Rienner : 165-184.

Mac Cormack C., 1992, "Planning and evaluating women'd participation in primary health care", Social science and medicine, 35,6:831-837.

Made P.A., Nyorovai Whande, 1989, "Women in Southern Africa : a note on Zimbabwean 'success story' ", Issue 17, 2 : 26-28.

Manicom L., 1992, "Ruling relations : rethinking state and gender in South African history", Journal of African history, 33, $3: 441-465$.

Marshall R., 1993, "Power in the name of Jesus : social transformation and Pentecostalism in Western Nigeria revisited", in Ranger T. \& Vaughan O., Legitimacy and the State in Twentieth-Century Africa, Oxford, St Antony's College : 213-246.

Martin S., 1984, "Gender and innovation : farming, cooking and pa1m processing in the Ngw a region, South-Eastern Nigeria, 1900-1930", Journal of African History, 25,4 : 411-427.

Mascarenhas O., 1999, Kigogo and Hananasif in Dar-es-Salaam, Tanzania. Gender aspects of urbanisation and natural resource management, in Lee-Smith D., Women managing resources. African research on gender, urbanisation and environment, Nairobi, Mazingira Institute : 52-79.

Matsuzono M., 1997, "Male involvement in family planning in Gusii society : an anthropological overview", African Study Monographs, 18,3-4 : 175-190.

Mayuyuka Kauda J., 1990, "Aricultural credit policy, bureaucratie decision-making and the subordination of rural women in the development process : some observations on ...", Journal of Southern African Studies, 16, $3:$ 413-430.

Mbow P., 1997, "Les femmes, l'Islam et les associations religieuses au Sénégal. Le dynamisme des femmes en milieu urbain", in Rosander E.E, Transformation des identités féminines en Afrique de l'Ouest, Uppsala, Nordiska Afrikainstitutet : 148-159.

Meena R., 1989, "Crisis and structural adjustment : Tanzanian women's politics", Issue, 17,2 : 29-31.

Meintel D., 1987, "Dix ans plus tard ... les études féministes en anthropologie", Anthropologie et Sociétés, II, $1: 1-8$.

Messer E., 1997, "Intra-household allocation of food and health care : current findings and understandings", Social Science and Medicine, 44, 11 : 1675-1684.

Mikell G., 1988, "Sexual complementarity in traditional Ghanaian society", Revue canadienne des Etudes africaines, 22, 3 : 656-661.

Molyneux M., 1998 "Analysing women's movements", Development and Change, 29, 2 : 219-245.

Moore H., Vaughan M.,1994, Cutting down trees. Gender, nutrition, and agricultural change in the Northern Province of Zambia, 1890-1990, London, Portsmouth NH. 
Munroe R.L., Munroe R.H., 1997, "Logoli childhood and the cultural reproduction of sex differenciation", in Weisner T.S. ; Bradley C. \& Kilbride P.L., African families and the crisis of social change, Westport, London, Bergin \& Garvey : 299-314.

Nelsen N., 2000, "Genderizing Nairobi's urban space", in Grigon, F. \& Maupeu H., L'Afrique orientale, Annuaire 2000, Paris, l'Harmattan : 169-323.

Nii-Amoo D.,Van Landewijk P., 1996, "Men, women, and the fertility question in Sub-Saharan Africa : an example from Ghana", African Studies Review, 39, $3: 29-41$.

Nyamba A., 1998, "Paroles de femme, pouvoir de femme. Ou les conditions féminines de l'autorité mâle chez les Sanan du Burkina Faso", Civilisations, 45,1-2 : 85-114.

Nyanchama Okemwa S., 1999, "Wombs and graves, witches and whores. Gusii paradoxes in a context of land commodification", in De Lame D. \& Zabus C., Changements au féminin en Afrique Noir, vol. 1 : Anthropologie, Paris, l'Harmattan : 147-182.

Odubogun K., 1994, "Poverty alleviation in Africa : a review of strategies", African Quaterly, 34,4 : 1-16.

Okeke P., 1997, "Africa! Africanist feminist relations : restructuring the agenda/agency", Issue, $25,2: 34-36$

Okojie Ch. E.E., 1984, "Female migrants in the urban labour market : Benin City, Nigeria", Revue canadienne des Etudes africaines, 18,3 : 547-562.

Okonjo Kamene, 1989, "Rural development in Nigeria : how do women count ?", Africana Marburgensia, 22, $1: 32-51$.

Olenja JM., 1991, "Gender and agricultural production in Samia, Kenya : strategies and constraints", Journal of Asian and African Studies, 26, 3-4 : 267-275.

Olurode L., 1995, "Women in rural-urban migration in the town of Iwo in Nigeria", in Baker J. \& Akin A.T., The migration experience in Africa, Sweden, Nordiska Afrikainstitutet : 289-302.

Olusi J., 1997, "Enhancing female participation in African agriculture transformation : the Nigerian experience", Issue 25, $2: 12-15$.

Omari C.K., 1995, Women in the informal sector, Dar es Salaam, University Press.

Orubuloye I., Caldwell J., Caldwell P., 1997, "Perceived male sexual needs and male sexual behaviour in South-West Nigeria", Social Science and Medicine 44,8 : 1195-1207.

Ouedraogo J.B., 1995, "The girls of Nyovuuru. Dagara female labour migrations to Bobo-Dioulasso", in Baker J. \& Akin AT., The migration experience in Africa Sweden, Nordiska Afrikainstitutet : 303-320.

Parpart J.L., 1988, Women and the state in Africa, in Rotchild D. \& Chazan N., The precarious balance. State and society in Africa, Boulder, London, Westview Press : 208-230.

Pellow D., 1987, "Solidarity among Muslim women in Accra, Ghana", Anthropos, 82, 4-6 : 489-506.

Pere M., 1987, "Femmes en pays lobi : animatrices rurales", Communautés, nº 79 : 32-37.

Postel-Coster E., 1987, "Développement rural et marginalisation des femmes au Mali du Sud", Anthropologie et Sociétés, 11, $1: 107-114$.

Peters P.E., 1995, "Uses and abuses on the concept of 'female-headed households' in research on agrarian transformation and policy", in Fay Bryceson D., Women wielding the hoe. Lessons from rural Africa for feminist theory and development practice, Oxford, Washington DC, Berg Publishers : 93-108. 
Pillay P., 1985, "Women in employment : some important trends and issues", Social dynamics, $11,2: 31-37$.

Piot Ch.D., 1992, "Wealth production, ritual consumption, and center/periphery relations in a West African regional system", American ethnologist, 19, 1 : 34-52.

Piron F., Couillard M.A., 1996, "Présentation. Les usages et les effets sociaux du savoir scientifique", Anthropologie et Sociétés, 20, 1 : 7-26.

Pitcher A., 1996, "Conflict and cooperation : gendered roles and responsibilities within cotton households in Northern Mozambique", African Studies Review, 39, $3:$ 81-112.

Pittin R., 1991, "Women, work and ideology in Nigeria", Review of African Political Economy, $\mathrm{n}^{\circ} 52$ : 38-52.

Pittin R., 1990, "Selective education : issues of gender, class and ideology in Northern Nigeria", Review of African Political Economy, $\mathrm{n}^{\circ} 48$ : 7-25.

Plaza M., 1997, "Femmes et sida dans le discours médical : la force des images", Journal des Anthropologues, $\mathrm{n}^{\circ}$ 68-69: 47-56.

Preiswerk Y., 1999, Tant qu'on a la santé. Les déterminants socio-économiques et culturels de la santé dans les relations sociales entre..., Genève, IUED.

Rahman A., Toubia N., 2000, Female genital mutilation. A guide to laws and policies world-wide, London, Zed Books.

Ramamonjisoa S., 1993, "Empowerment of women and democracy in Madagascar", Review of African Political Economy, ${ }^{\circ} 58: 118-123$.

Rasmussen S.J., 1994, "Female sexuality, social reproduction, and the politics of medical intervention in Niger : Kel Ewey Tuareg perspectives", Culture, Medecine and Psychiatry, 18,4 : 433-462.

Riphenburg C., 1997, "Changing gender relations and structural adjustment in Zimbabwe", Africa, 52,2:237-260.

Riphenburg C., 1997, "Women's status and cultural expression : changing gender relations and structural adjustment in Zimbabwe", Africa Today, 44, 1 : 33-50.

Risseuw C., Ganesh K., 1995, Negotiation and social space. Agendered analysis of changing kin and security networks in South Asia and Sub-Saharan Africa, London, Sage Publications.

Roberts P., 1985, "Les femmes et les programmes de développement rural avec référence aux programmes-femmes financés par le Fonds européen de ...", Tiers Monde 26, n 102 : 299-305.

Rodriguez-Torres D., 1999, "La libre entreprise au féminin. Une typologie de la prostitution à Nairobi", Kenya, in De Lame D. \& Zabus C., Changements au féminin en Afrique Noire, vol. 1 : Anthropologie, Paris, l'Harmattan : 115-145.

Rosander E.E., 1997, Transforming female identities. Women's organizational forms in West Africa, Uppsala, Nordiska Afrikainstitutet.

Ryan J., 1994, "Women, modernity and the city", Theory, Culture and Society, 11, 4 : 35-63.

St Hilaire C., 1996, "La production d'un sujet-femme adapté au développement. Le cas de la recherche féministe aux Philippines", Anthropologie et Sociétés, 20, 1: 81-102.

Salamone Fr.A., 1986, "Religion and repression : enforcing feminine inequality in an 'egalitarian society' ", Anthropos, 81,4-6. 
Saunders B., 1999, Des fantasmes de genre dans le système monde (et de ce qu'il convient d'en faire), in De Lame D. \& Zabus C., Changements au féminin en Afrique Noire, vol. II : Littérature, Paris, l'Harmattan : 143-155.

Schoenbrun D., 1998, A Green Place, a Good Place. Agrarian Change, Gender, and Social Identity in the Great Lake Region to the 15th Century, Oxford, Currey.

Schoepf B.G., 1987, "Social structure, women's status and sex differential nutrition in the Zaïrian Copperbelt", Urban Anthropology ,16, 1 : 73-102.

Schroeder R., 1996, " 'Gone to their second husbands' : marital metaphors and conjugal contracts in the Gambia's female garden sector", Revue canadienne des Etudes africaines, 30,1 : 69-87.

Schroeder R.A., 1999, Shady practices. Agroforestry and gender politics in the Gambia, Berkeley, Los Angeles, London, University of California Press.

Silberschmidt M., 1992, "Have men become the weaker sex ? Changing life situations in Kisii District, Kenya", Journal of Modern African Studies, 30, 2 : 237-253.

Silberschmidt M., 1999, Women forget that men are the masters. Gender antagonism and socio-economic change in Kisii district, Kenya, Uppsala, Nordiska Afriakainstitutet.

Simard P., Pelchat Y., Tall Thiam K., 1994, "Recherche sociale, solidarité et rapports de genre : à propos d'une étude sur les migrantes Serer à Dakar", Apad Bulletin, nº 8 : 42-51.

Skeggs B., 1997, Formations of class and gender, London, Sage.

Skjonsberg E., 1995, "Documenting women's views through participatory research : diaries of daily activities in rural Zambia", in Fahy Bryceson D., Women wielding the Hoe. Lessons from rural Africa for feminist theory and development practice, Oxford, Washington DC, Berg Publishers : 225-236.

Smith O.R., 1996, "Whose cows are they, anyway ? Ideology and behavior in Nandi cattle "ownership" and control", Human ecology, 24,2 : 255-272.

Smith R., 1998, "Money breaks blood ties : chiefs courts and the transition from lineage debt to commercial debt in Sipolibo district", Journal of Southern African Studies, 24, 3 : 509-526.

Snyder K., 1997, "Elders authority and women's protest : the Masay ritual and social change among the Iraqw of Tanzanie", Journal of the Royal Anthropological Institute, 3, $3: 561-576$.

Sow F., 1987, "Femmes africaines, emploi et division internationale du travail", Présence africaine, $\mathrm{n}^{\circ} 141: 195-226$.

Staudt K., 1987, "Women farmers in Africa : research and institutional action, 1972 -1987", Revue canadienne des Etudes africaines, 22, 3 : 567-582.

Strathern M., 1985, "Kinship and economy : constitutive orders of a provisional kind", American ethnologist, 12,2:191-209.

Strathern M., 1987, "L'étude des rapports sociaux de sexe : évolution personnelle et évolution des théories anthropologiques", Anthropologie et Sociétés, 11,1 : 9-18.

Suggs D., 1996, "Mosadi Tshwene : the construction of gender and the consumption of alcohol in Botswana", American Ethnologist, 13,3 : 597-610.

Sugiyama Y., 1992, "The development of Maize cultivation and changes in the village life of the Bemba of Northern Zambia", Senri Ethnological Studies, n $31: 173-201$. 
Talle A., 1987, "Women as heads of houses : the organization of production and the role of women among pastoral Maasai in Kenya", Ethnos, 52, 1-2 : 50-80.

Talle A., 1988, Women at a loss. Changes in Maasai pastoralism and their effects on gender relations, Stockholm University, Department Soc. Anthrop.

Tansel A., 1997, "Schooling attainment, parental education, and gender in Côte d'Ivoire : and Ghana", Economie Development and Cultural Change, 45, 4 : 825-856.

Thomas-Slayter B., Rocheleau D., 1998, Gender, environment and development in Kenya. A grassroot perspective, Boulder, London, Lynne Riener.

Trager L., 1995, Women migrants and rural-urban linkages in South-Western Nigeria, in Baker J., Akin Aina T., The Migration experience in Africa, Sweden, Nordiska Afrikainstitutet : 269-288.

Traore A., 1984, "Des conséquences de la sous-représentation statistique des femmes sur le développement national", Annales de l'Université d'Abidjan série F, 12 : 139-164.

Tubiana M.J., 1999, "Hommes, femmes : méthodes d'enquête", in Jonckers D., Carré R. \& Dupré M.C., Femmes plurielles. Les représentations des femmes : discours, normes et conduites, Paris, Maison des Sciences de l'Homme : 13-19.

Tusingwire H., Tumushabe J., 1999, "Women and control of housing in Kampala, Uganda. Characteristics and problems of women household heads", in Lee-Smith D., Women managing resources. African research on gender, urbanisation and environment, Nairobi, Mazingira Institute : 104-128.

Van der Vliet V., 1991, "Traditional husbands, modem wives ? Constructing marriages in a South African township", African Studies, 50, 1-2 : 219-241.

Verschuur Ch., 2000, Quel genre d'homme? Construction sociale de la masculinité, relations de genre et développement, Genève, IUED.

Von Bülow D., 1992, "Bigger than men ? Gender relations and their changing meaning in Kipsigis society, Kenya", Africa, 62,4 :523-546.

Von Bülow D., Sorensen A., 1993, "Gender and contract farming : tea outgrower schemes in Kenya", Review of African Political Economy, n 56 : 38-52.

Wakoko P., Lobao L., 1996, "Reconceptualizing gender and reconstructing social life : Uganda women and the path to national development", Africa Today, 43,3:307-322.

Wamock K., 1995, "Women, war and humanitarian intervention : resources for NGOs. Relief and Rehabilitation", Network Newsletter, $\mathrm{n}^{\circ} 4: 12-15$.

Warren C.A.B., 1988, Gender issues in field research. Newbury Park, London, Sage Publications.

Webster D., 1991, "Abafazi bathonga bafihlakala'. Ethnicity and gender in a KwaZulu border community", African Studies, 50, 1-2.

Weisner T.S., Bradley C., Kilbride P.L., 1997, African families and the crisis of social change, Westport, London, Bergin \& Garvey.

Yuval-Davis N., 1997, "Ethnicity, gender relations and multiculturalism", in Werbner P. \& Modoot T., Debating cultural hybridity. Multi-cultural identities and the politics of anti-racism, London, Zed Books : 193-208.

Zamberia A., 1996, "Self-help secondary education in Kenya", International Journal of Comparative Sociology, 37,1-2. 
Zeleza T., 1988, "Women and the labour process in Kenya since independance", Transafrican Journal of History, 17 : 69-10

\section{NOTES}

1.La bibliographie qui est proposée ici est une bibliographie sélective compilée à partir de la base de données du Centre de Documentation en Sciences humaines sur l'Afrique noire du Musée royal de l'Afrique centrale à Tervuren (Belgique). Danielle de Lame a effectué une sélection de titres postérieurs à 1988. Cette sélection fera peut-être découvrir des articles spécifiques égarés dans les pages d'ouvrages collectifs, des publications en anglais moins connues des francophones et inversement. Elle illustre, quoi qu'il en soit, la diversité des thèmes traités ces dernières années dans le cadre des rapports de genre et l'attention toute récente accordée à la masculinité. L'article introductif au volume évoque les tendances de ces publications. Le service de linguistique du MRAC est ici remercié pour sa contribution à la mise en forme de cette compilation. 